\title{
Demam pada Anak
}

\author{
Ismoedijanto
}

Demam pada anak merupakan salah satu masalah yang masih relevan untuk para praktisi pediatri. Demam merupakan tanda adanya kenaikan set-point di hipotalamus akibat infeksi atau adanya ketidakseimbangan antara produksi dan pengeluaran panas. Sebaliknya tidak semua anak yang terkena infeksi akan menunjukkan gejala demam, semakin muda umurnya, semakin tidak jelas gambaran klinisnya. Tindakan pada anak dengan demam diawali dengan pertimbangan apakah ada kegawatan, apa penyebabnya dan apakah demam perlu segera diturunkan. Agar tindakan tersebut tepat dan terarah, diperlukan suatu pengelompokan / klasifikasi pasien agar dapat digunakan suatu algoritma umum. Pada tiap kelompok tetap ada kriteria kegawatan, kriteria jenis infeksi yang mengarah kepada tindakan yang diambil, terutama perawatan dan pemberian antibiotik secara empirik. Tindakan yang dilaksanakan sebaiknya bukan tindakan yang sifatnya sesaat, tetapi merupakan tindakan yang berkesinambungan, sampai pasien lepas dari masalahnya. Keputusan untuk dirawat harus dilanjutkan dengan pemeriksaan laboratorium dan pemberian antibiotik empirik. Tindakan lanjutan akan disesuaikan dengan hasil pemeriksaan penunjang, respons pasien terhadap pengobatan sampai masalahnya selesai dengan tuntas.

Kata kunci: Demam - set point hipothalamus - algoritme - antibiotik empiris

$\mathscr{A}$ nak yang menderita demam merupakan sebagian dari pasien yang berobat ke dokter anak $(19-30 \%)^{1}$ dan pada umumnya tidak ada seorang dokter anak manapun yang merasa nyaman menghadapi anak dengan demam. Demam dapat merupakan tanda permulaan adanya infeksi, namun demam juga bisa disebabkan oleh adanya kelainan metabolik dan sebab-sebab lain ${ }^{2}$. Masalah demam pada anak sifatnya terbuka, banyak sekali kemungkinan yang tak terduga. Tidak ada prosedur tetap yang pasti berhasil, petunjuk yang ada hanyalah semacam garis besar yang harus diterjemahkan dengan kedalaman pengetahuan, kreasi dan art dari dokter yang menanganinya sesuai dengan keadaan pasien. Setiap dokter anak harus mencoba menemukan

Alamat korespondensi:

Dr. Ismoedijanto Sp.A (K)

Divisi Penyakit Infeksi dan Pediatri Tropik, Bagian Ilmu Kesehatan Anak FKUNAIR/RS Dr. Soetomo, Jl. Prof. Dr. Moestopo no. 6-8. Surabaya, Indonesia Telpon 031-5501748/5501680, Fax. 031-5938735. kegawatan yang diderita anak dengan demam, apakah demam tersebut merupakan tanda penyakit yang gawat yang harus segera ditangani secara serius atau tidak.

Tulisan ini terutama menitikberatkan pada tindakan yang perlu dilakukan pada pasien dengan demam, sesuai dengan klasifikasinya.

\section{Demam}

Definisi demam adalah keadaan suhu tubuh di atas suhu normal, yaitu suhu tubuh di atas $38^{\circ}$ Celsius. Suhu tubuh adalah suhu visera, hati, otak, yang dapat diukur lewat oral, rektal, dan aksila., ${ }^{1,2,3}$ Cara pengukuran suhu menentukan tinggi rendahnya suhu tubuh. Pengukuran suhu melalui mulut dilakukan dengan mengambil suhu pada mulut (mengulum termometer dilakukan pada anak yang sudah kooperatif), hasilnya hampir sama dengan suhu dubur, namun bisa lebih rendah bila frekuensi napas cepat. Pengukuran suhu melalui dubur (rektal) dilakukan 
pada anak di bawah 2 tahun. Termometer masuk ke dalam dubur sedalam $2-3 \mathrm{~cm}$ dan kedua pantat dikatupkan, pengukuran dilakukan selama 3 menit. Suhu yang terukur adalah suhu tubuh yang mendekati suhu yang sesungguhnya (core temperature). Dikatakan demam bila suhu di atas $38^{\circ} \mathrm{C}$.

Pengukuran suhu melalui ketiak (axilar) hanya dapat dilakukan pada anak besar mempunyai daerah aksila cukup lebar, pada anak kecil ketiaknya sempit sehingga terpengaruh suhu luar. Pastikan puncak ujung termometer tepat pada tengah aksila dan pengukuran dilakukan selama 5 menit. Hasil pengukuran aksila akan lebih rendah $0,5-1,0^{\circ} \mathrm{C}$ dibandingkan dengan hasil pengukuran melalui dubur. Pengukuran suhu dengan cara meraba kulit, daerah yang diraba adalah daerah yang pembuluh darahnya banyak seperti di daerah pipi, dahi, tengkuk. Meskipun cara ini kurang akurat (tergantung kondisi tangan ibu), namun perabaan ibu cukup bisa dipercaya dan digunakan sebagai tanda demam pada program MTBS (Manajemen Terpadu Balita Sakit).

\section{Pengaturan Suhu Tubuh}

Suhu adalah hasil produksi metabolisme tubuh yang diperlukan untuk kelancaran aliran darah dan menjaga agar reaksi kimia tubuh dapat berjalan baik (enzim hanya bekerja pada suhu tertentu). Sebagai makhluk yang homeotermik, anak selalu berusaha mengatur suhu tubuhnya. Suhu tubuh diatur oleh suatu mekanisme yang menyangkut susunan saraf, biokimia, dan hormonal. Hipotalamus menerima informasi suhu tubuh bagian dalam dari suhu darah yang masuk ke otak dan informasi suhu luar tubuh dari reseptor panas di kulit. Termostat dalam hipotalamus diatur pada set-point sekitar suhu $37^{\circ} \mathrm{C}$ dengan rentang sekitar $1^{\circ} \mathrm{C}$, dan suhu dipertahankan dengan menjaga keseimbangan pembentukan atau pelepasan panas. Saraf eferen dari hipotalamus terdiri dari saraf somatik dan saraf autonom, sehingga hipotalamus dapat mengatur aktifitas otot, kelenjar keringat, peredaran darah, dan ventilasi paru. Hipotalamus posterior merupakan pusat pengatur yang bertugas meningkatkan produksi panas dan mengurangi pengeluaran panas. Bila suhu luar lebih rendah, pembentukan panas akan dilakukan dengan meningkatkan metabolisme, dengan mekanisme kontraksi otot / menggigil, pengeluaran panas akan dikurangi dengan vasokonstriksi pembuluh darah kulit dan pengurangan produksi keringat. Hipotalamus anterior merupakan pusat pengatur pengeluaran panas. Bila suhu di luar tubuh lebih tinggi maka pengeluaran panas ditingkatkan dengan cara vasodilatasi, evaporasi (berkeringat), radiasi (dipancarkan), kontak (bersinggungan/ kompres), aliran (dari daerah panas ke dingin), dan konveksi. ${ }^{2,3,4}$ Permukaan tubuh anak relatif lebih luas dibandingkan dewasa, sehingga proses penguapan dan radiasi sangat penting, terutama untuk daerah tropis.

\section{Penyebab Demam}

Demam merupakan akibat kenaikan setpoint (oleh sebab infeksi) atau oleh adanya ketidakseimbangan antara produksi panas dan pengeluarannya. Demam pada infeksi terjadi akibat mikro organisme merangsang makrofag atau PMN membentuk PE (faktor pirogen endogenik) seperti IL-1, IL-6, TNF (tumuor necrosis factor), dan IFN (interferon). Zat ini bekerja pada hipotalamus dengan bantuan enzim cyclooxygenase pembentuk prostaglandin. Prostaglandin-lah yang meningkatkan set point hipotalamus. Pada keadaan lain, misalnya pada tumor, penyakit darah dan keganasaan, penyakit kolagen, penyakit metabolik, sumber pelepasan PE bukan dari PMN tapi dari tempat lain. ${ }^{1,2,3,4}$ Kemampuan anak untuk beraksi terhadap infeksi dengan timbulnya manifestasi klinis demam sangat tergantung pada umur. Semakin muda usia bayi, semakin kecil kemampuan untuk merubah set-point dan memproduksi panas. Bayi kecil sering terkena infeksi berat tanpa disertai dengan gejala demam.

\section{Patofisiologi Demam}

Secara teoritis kenaikan suhu pada infeksi dinilai menguntungkan, oleh karena aliran darah makin cepat sehingga makanan dan oksigenasi makin lancar. Namun kalau suhu terlalu tinggi (di atas $38,5^{\circ} \mathrm{C}$ ) pasien mulai merasa tidak nyaman, aliran darah cepat, jumlah darah untuk mengaliri organ vital (otak, jantung, paru) bertambah, sehingga volume darah ke ekstremitas dikurangi, akibatnya ujung kaki/tangan teraba dingin. Demam yang tinggi memacu metabolisme yang sangat cepat, jantung dipompa lebih kuat dan cepat, frekuensi napas lebih cepat. Dehidrasi terjadi akibat penguapan kulit dan paru dan disertai dengan ketidakseimbangan 
elektrolit, yang mendorong suhu makin tinggi. Kerusakan jaringan akan terjadi bila suhu tubuh lebih tinggi dari $41^{\circ} \mathrm{C}$, terutama pada jaringan otak dan otot yang bersifat permanen. Kerusakan tersebut dapat menyebabkan kerusakan batang otak, terjadinya kejang, koma sampai kelumpuhan. Kerusakan otot yang terjadi berupa rabdomiolisis dengan akibat terjadinya mioglobinemia. $3,4,7$

\section{Klasifikasi Demam untuk Menentukan Tindakan}

Demam dapat merupakan satu-satunya gejala yang ada pada pasien infeksi. Panas dapat dibentuk secara berlebihan pada hipertiroid, intoksikasi aspirin atau adanya gangguan pengeluaran panas, misalnya heatstroke. Klasifikasi dilakukan berdasar pada tingkat kegawatan pasien, etiologi demam, dan umur. ${ }^{5,6,8,9,10}$

Klasifikasi berdasarkan umur pasien dibagi menjadi kelompok umur kurang dari 2 bulan, 3-36 bulan dan lebih dari 36 bulan. Pasien berumur kurang dari 2 bulan, dengan atau tanpa tanda SBI (serious bacterial infection). Infeksi seringkali terjadi tanpa disertai demam. Pasien demam harus dinilai apakah juga menunjukkan gejala yang berat. ${ }^{11}$ Menurut Yale Acute Illness Observation Scale atau Rochester Criteria, yang menilai adakah infeksi yang menyebabkan kegawatan. Pemeriksaan darah (leukosit dan hitung jenis) dapat merupakan petunjuk untuk perlunya perawatan dan pemberian antibiotik empirik.

Klasifikasi berdasarkan lama demam pada anak, dibagi menjadi:

1. Demam kurang 7 hari (demam pendek) dengan tanda lokal yang jelas, diagnosis etiologik dapat ditegakkan secara anamnestik, pemeriksaan fisis, dengan atau tanpa bantuan laboratorium, misalnya tonsilitis akut.

2. Demam lebih dari 7 hari, tanpa tanda lokal, diagnosis etiologik tidak dapat ditegakkan dengan amannesis, pemeriksaan fisis, namun dapat ditelusuri dengan tes laboratorium, misalnya demam tifoid.

3. Demam yang tidak diketahui penyebabnya, sebagian terbesar adalah sindrom virus.

Di samping klasifikasi tersebut di atas, masih ada klasifikasi lain yaitu klasifikasi kombinasi yang menggunakan tanda kegawatan dan umur sebagai entry, dilanjutkan dengan tanda klinis, lama demam dan daerah paparan sebagai kriteria penyebab, seperti terlihat pada algoritme di bawah ini.

\section{Pendekatan Tatalaksana}

Pada tahap tertentu demam dapat menguntungkan pasien dalam arti dapat meningkatkan fagositas dan menurunkan viabilitas kuman, meskipun penelitian yang ada belum mendukung manfaat klinisnya. Namun kecemasan orang tua dan keraguan dokter mendorong tindakan menurunkan demam, meskipun tindakan itu dapat mengaburkan gejala dan obat yang dipakai belum tentu aman dari risiko sindrom Reye, intoksikasi salisilat, dan gangguan hati. Penurunan demam harus sesuai dengan klasifikasi penyebabnya, apakah perlu menurunkan set-point atau dengan cara lain.

Tata laksana anak dengan demam terdiri dari tatalaksana fisis, dan pengobatan baik simtomatik maupun etiologik.

\section{Tindakan Umum Penurunan Demam secara Simtomatik}

Diusahakan agar anak tidur atau istirahat agar metabolismenya menurun. Cukupi cairan agar kadar elektrolit tidak meningkat saat evaporasi terjadi. Aliran udara yang baik misalnya dengan kipas, memaksa tubuh berkeringat, mengalirkan hawa panas ke tempat lain sehingga demam turun. Jangan menggunakan aliran yang terlalu kuat, karena suhu kulit dapat turun mendadak. Ventilasi / regulasi aliran udara penting di daerah tropik. Buka pakaian/selimut yang tebal agar terjadi radiasi dan evaporasi. Lebarkan pembuluh darah perifer dengan cara menyeka kulit dengan air hangat (tepid-sponging). Mendinginkan dengan air es atau alkohol kurang bermanfaat (justru terjadi vasokonstriksi pembuluh darah), sehingga panas sulit disalurkan baik lewat mekanisme evaporasi maupun radiasi. Pada hipertermi, pendinginan permukaan kulit (surfacecooling) dapat membantu.

Tindakan simtomatik yang lain ialah dengan pemberian obat demam. Cara kerja obat demam adalah dengan menurunkan set-point di otak dan membuat pembuluh darah kulit melebar sehingga pengeluaran 


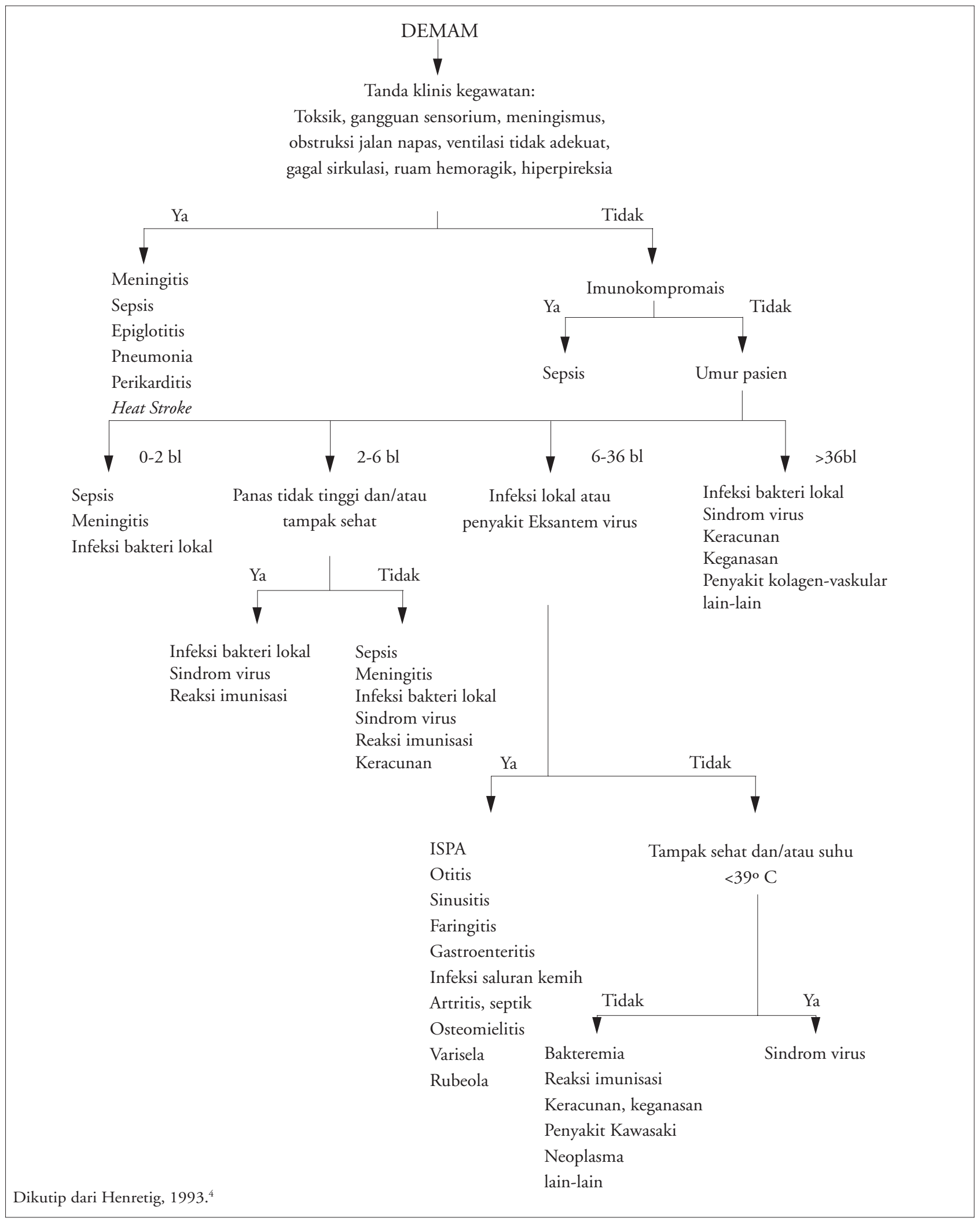

Bagan Algoritme Demam pada Anak 
panas ditingkatkan. Obat yang sederhana adalah asam salisilat dan derivatnya. Rentang daya kerja obat ini cukup panjang, aman untuk dikonsumsi umum. Beberapa golongan antipiretik murni, dapat menurunkan suhu bila anak demam namun tidak menyebabkan hipotermi bila tidak ada demam, seperti: asetaminofen, asetosal, ibuprofen. Obat lain adalah obat yang bersifat antipiretik pada dosis rendah dan menimbulkan hipotermi pada dosis tinggi seperti metamizol dan obat yang dapat menekan pusat suhu secara langsung (chlorpromazine), mengurangi menggigil namun dapat menyebabkan hipotermi dan hipotensi. ${ }^{3,4,8,12}$

\section{Tatalaksana Demam yang Disebabkan Penyakit Infeksi}

Pengobatan dilakukan sesuai dengan klasifikasi etiologik. Kesukaran yang dihadapi adalah pola penyakit yang berbeda baik dari aspek geografik maupun umur pasien. Bagan di atas tidak dapat diterapkan begitu saja pada daerah endemik malaria atau daerah endemik demam berdarah. Sekali lagi sifat paparan, letak geografik sangat mempengaruhi etiologi demam pada anak. Pemberian antibiotik pertama dan hospitalisasi sangat juga dipengaruhi oleh fasilitas sarana perawatan dan pemeriksaan penunjang. Setiap rumah sakit seharusnya mempunyai pedoman diagnosis dan terapi tersendiri, tergantung pada pola epidemiologik penyakit tersebut. Pada penelitian MTBS tahun 1998, di Indonesia etiologi demam pada anak sebagian besar (lebih dari $80 \%$ ) adalah infeksi. ${ }^{13,14}$

\section{Tatalaksana Demam Menurut Umur}

Tatalaksana demam pada bayi kecil telah mengalami perubahan yang cukup signifikan. Pada kelompok bayi dengan usia kurang 2 bulan, pendekatan yang umum dilakukan ialah hospitalisasi untuk mendapatkan pengobatan antimikrobial empirik. Pada tahun 1993, para ahli infeksi, gawat darurat dan kesehatan anak sepakat melakukan pendekatan lebih konservatif dengan cara rawat jalan untuk kasus-kasus ini, bila risiko terhadap SBI rendah. Salah satu pendekatan yang dapat dilakukan untuk mengurangi perawatan adalah dengan menggunakan penyaring: Yale Acute Illness Observation Scale atau kriteria
Rochester. Pada kelompok ini bila hasil laboratorium menunjukkan adanya tanda infeksi (leukosit darah $<5.000$ atau $>15.000$, hitung neutrofil darah $>1500$, leukosit urin di atas $10 / \mathrm{lpb}$, leukosit tinja $>5 / \mathrm{lpb}$ ), anak segera masuk RS dan langsung mendapatkan pengobatan antimikrobial secara empirik. Pada kelompok yang tidak memenuhi kriteria ini, maka ada 2 pilihan yaitu: 1 . melakukan kultur urin, kultur darah, kultur cairan serebro spinalis, diberikan ceftriaxon dan diminta kontrol kembali setelah 24 jam. 2. melakukan kultur urin dan observasi dulu. Pada anak dengan usia kurang dari 28 hari, pendekatan sebaiknya lebih agresif dengan langsung memasukan ke RS untuk mendapatkan terapi antimikrobial secara empirik. Pada kelompok usia 336 bulan, risiko adanya bakteriemia pada anak dengan demam sekitar 3-11\%. Bakteriemia tidak terjadi pada kelompok ini bila: leukosit $<15.000$ dengan suhu $>39^{\circ} \mathrm{C}$, sedang kemungkinan bakteriemia akan 5 kali lipat bila lekosit $>15.000$. Pada kelompok belakangan ini langsung dilakukan kultur darah dan pemberian ceftriaxon. Pada kelompok anak di atas 36 bulan, pengobatan bisa dilakukan secara etiologik, dengan memperhatikan adanya kegawatan.

Pada akhirnya apapun yang dianjurkan akan tetap menimbulkan perdebatan. Tidak ada satu standar yang harus ditaati untuk dijadikan pegangan. Semua tindakan tetap harus dilakukan berdasarkan pada anamnesis yang tajam dan terarah, dan pemeriksaan fisis yang teliti. Kecenderungan dokter untuk bertindak, sangat dipengaruhi oleh pengalaman yang mereka dapat dan keluasan pengetahuan yang dimiliki. Pilihan antara melakukan tes atau tidak, melakukan pemberian antibiotik atau observasi, sangat tergantung pada pendirian dan kepribadian dokter.

- Anak yang tampak toksik harus segera mendapat tindakan yang segera

- Semakin muda, semakin tinggi ketidak tentuan klinisnya

- Anak yang tidak tampak toksik dapat menyulitkan, karenanya perlu pengamatan yang sangat ketat

- Tidak perlu selalu melakukan pemeriksaan penunjang dan bila dilakukan pemeriksaan penunjang, tindakan harus sesuai dengan hasilnya

- Catat dengan cermat apa yang dilakukan atau tidak dilakukan

- Tidak ada aturan baku yang harus ditaati 
Sari Pediatri, Vol. 2, No. 2, Agustus 2000

\section{Daftar Pustaka}

1. Kliegman RM, Behrman RE. Fever. Dalam: Behrman RE Kliegman RM, Nelson WE, Vaughn VC, penyunting. Nelson textbook of pediatrics, edisi 14, Philadelphia: WB Saunders, 1992;h.647-56.

2. Sinclair JC. The control of body temperature and the pathogenesis of fever: developmental aspects. Dalam: Annales Nestle: Fever in children. Vevey, Switzerland: Nestle Nutrition SA, 1984;h.1-10.

3. Hardiono D Pusponegoro. Penatalaksanaan demam pada anak.

4. Henretig FM. Fever. Dalam: Fleisher GR, Ludwig S, penyunting. Textbook of pediatric emergency medicine; edisi ke-3. Baltimore: Williams dan Wilkins, 1993;h.20210.

5. Dechovitz AB, Moffet HL. Classification of acute febrile illnesses in childhood. Clin Pediatr 1968; 7:649.

6. Departemen Kesehatan. Manajemen terpadu balita sakit.
Modul klasifikasi dan menentukan tindakan, 1999.

7. Mortimer JG. Fever of unknown origin in children: Investigation and management. J Paed Obs and Gyn, $1981 ; 7: 27-32$

8. Darwis D, Ismail S. Penatalaksanaan hiperpireksia pada anak. Dalam: Iwan Darmansyah dan Suharti KS, penyunting. Penatalaksanaan demam bagian farmakologi FKUI dan IDI JAKPUS, Jakarta:1982;h.63-70.

9. Schmitt BD. Fever phobia: Misconception of parents about fevers. Am J Dis Child 1980; 134:176-81.

10. Finkelstein J, Christiansen CL, Platt R. Fever in pediatric primary care: Occurance, management and outcomes. Pediatr 2000; 105:260-6.

11. Prober CG. Managing the febrile infant: No rules are golden. J Paed Obs and Gyn 2000; 26:13-20.

12. Santoso SO. Mekanisme kerja dan pemilihan obat antipiretik. Dalam: Iwan Darmansyah dan Suharti KS, penyunting. Penatalaksanaan demam. Bagian Farmakologi FKUI dan IDI, Jakarta, 1982;h.1-8. 